\title{
Hay intake in dual purpose cows supplemented with multinutritional blocks, during the transition dry-wet season
}

\author{
Ana María Herrera ${ }^{1 \dagger}$, Robert Mora ${ }^{1}$, Pablo Herrera ${ }^{2}$, Nelson Martínez ${ }^{3}$, Omar Colmenares $^{4}$ \\ and Beatríz Birbe ${ }^{2}$
}

${ }^{1}$ Universidad Nacional Experimental del Táchira. San Cristóbal, Venezuela; ${ }^{2}$ Universidad Nacional Experimental Simón Rodríguez. Valle de la Pascua, Venezuela;

${ }^{3}$ Universidad Central de Venezuela. Maracay., Venezuela; ${ }^{4}$ Universidad Rómulo Gallegos. San Juan de los Morros, Venezuela

\begin{abstract}
Introduction
In hilly areas of the Central Plains the production systems for dual purpose meat and milk (cheese), are characterized by low production yields (Montilla and Colina, 1998), determined by the strong seasonality (Picolli, 1991), availability of dry matter and low nutritive value in this area (Fuentes et al., 2002). These constraints expose a need to expand knowledge regarding the use of strategic supplementation, using non traditional local food resources in dual-purpose cattle grazing systems with low quality basal diet and their interaction with climatic factors such. One strategy of supplementation in cattle is the use of multinutritional blocks (MB), mainly of proteins and minerals, as a suitable alternative to offset food shortages. The present research work was carried out in order to evaluate the effect of supplementation with multinutritional blocks (MB) on hay intake in dual purpose cows.
\end{abstract}

\section{Material and methods}

The research was undertaken at the "Pozote" farm, located in the hilly area of the central plains of Venezuela, over a 60 day period during the transition dry-rainy season. A completely randomized design was used, with two treatments, using 20 crossbred cows ( $1^{\text {st }}$ or $2^{\text {nd }}$ calvers). The two treatments were: control group (CG) $=10$ animals with ad libitum basal diet and Supplemented Group (SG) $=10$ animals with diet basal ad libitum plus MB. The composition of MB was maize flour (15\%), saman fruit (8\%), cotton seed $(6 \%)$, urea $(10 \%)$, molasses (30\%), mineral salt $(15 \%)$, dismmonium phosphate $(4 \%)$, hay $(2 \%)$ and lime $(10 \%)$. For the basal diet these animals consumed milled hay of Cynodon nlemfuensis and crop residues of Sorghum bicolor in corrals, in the morning (5 hours/day), and the rest of the day were in paddocks with species including Cynodon nlemfuensis, Panicum maximun, Andropogon gayanus, Brachiaria arrecta and Dichanthium aristatum. For MB, hay and forage, values were determined for crude protein and ether extract (A.O.A.C., 1965), neutral detergent fiber (Goering and Van Soest, 1970), calcium (Fick et al., 1979) and phosphorus (Harris and Popat, 1954).

\section{Results}

These are given in Table 1. Average intake of MB was $67.92 \pm 21.41 \mathrm{~g} / 100 \mathrm{~kg}$ live weigh. Highly significant differences were observed $(P<0.01)$ in hay intake (SG $=457.55 \pm 216.45$ and $C G=213.82 \pm 81.12 \mathrm{~g} / 100 \mathrm{~kg}$ live weigh) during the test, favorable to SG. Equally, the maximum MB intake coincided with the maximum hay intake in SG, of 93.75 y $726.14 \mathrm{~g} / 100 \mathrm{~kg}$ live weigh respectively.

Table 1 Chemical composition of multinutritional block (MB), hay and forage offered in paddocks to dual purpose cows in central plains of Venezuela

\begin{tabular}{lccccrr}
\hline \hline & Ash & CP & EE & NDF & Ca & $P$ \\
\hline MB & 34.28 & 29.59 & 2.11 & 16.94 & 9.94 & 2.52 \\
Hay & 12.46 & 5.24 & 1.03 & 66.89 & 0.39 & 0.07 \\
Paddocks & 9.65 & 6.27 & 3.37 & 74.28 & 0.23 & 0.21 \\
\hline \hline
\end{tabular}

CP: crude protein; EE: ether extract; NDF: neutral detergent fiber; Ca: calcium; P: phosphorus.

\section{Conclusions}

It is possible that supplementation with MB improved cow rumen environment, creating a better use of available fiber resources, evidenced in the increasing consumption of hay.

\section{References}

Association of Official Analytical Chemists (AOAC) 1965. Official methods of the analysis association of official analytical chemistry. Washington, D.C. 957p.

\footnotetext{
${ }^{\dagger}$ E-mail: anamariaherreraangulo@yahoo.com
} 
Fick K, Mc Dowell L, Miles P, Wilkinson N, Conrad J and Valdivia R 1979. Análisis de espectrofotometría de absorción atómica, método de análisis de minerales para tejidos de plantas y animales, 2da ediciónLatin American Research Programme, Florida, pp. 701-702.

Fuentes H, Martínez N, Colmenares O, Drescher K, Herrera P and Birbe B 2002. Efectos de la época sobre parámetros reproductivos en novillas doble propósito en el estado Guárico. Revista Científica de la Facultad de Ciencias Veterinarias, LUZ 7, 439-441.

Goering $\mathrm{H}$ and Van Soest P 1970. Forage fibres analysis. Agricultural Research Service. U.S. Department of Agriculture. 30p.

Harris W and Popat P 1954. Determination of phosphorus content of lipids. Am. Oil. Chem. Soc. J. N 31, 124.

Montilla J and Colina J 1998. Productividad del rebaño bovino venezolano. En:. XIV Cursillo sobre bovinos de carne. Facultad de Ciencias Veterinarias. Universidad Central de Venezuela. pp. 23-35.

Picolli V 1991. Aspectos reproductivos de un rebaño de doble propósito y su relación con factores ambientales y bióticos en los llanos centrales. Trabajo de Grado. UCV-FCV, Maracay, Venezuela. 84p.

\title{
Effect of phenological stage on biomass production and chemical composition of Brachiaria ruziziensis for ruminant feeding
}

\author{
F. Tendonkeng ${ }^{1 \dagger}$, B. Boukila ${ }^{2}$, T. E. Pamo ${ }^{1}$ and A. V. Mboko ${ }^{2}$ \\ ${ }^{1}$ University of Dschang, FASA, Department of Animal Sciences, Laboratory of Animal Nutrition, PO Box: 222, Dschang, Cameroon; ${ }^{2}$ Institut National Supérieur \\ d'Agronomie et de Biotechnologie (INSAB) Université des Sciences Techniques de Masuku. B.P. 941 Masuku, Gabon
}

\section{Aim}

The study of the effect of phenological stage (bolting, flowering and seed set) on biomass production and chemical composition of Brachiaria ruziziensis for ruminant feeding was conducted at the University of Dschang teaching and research farm in 2008.

\section{Materials \& Methods}

A total of 24 plots of $8 \mathrm{~m}^{2}(4 \mathrm{~m} \times 2 \mathrm{~m})$ of Brachiaria ruziziensis were used at each phenological stage (bolting, flowering and seed set). The evaluation of the plant biomass was done on each plot. A representative sample of $1 \mathrm{~kg}$ of plants, taken during the measurement of biomass was dried at $60^{\circ} \mathrm{C}$ to evaluate the chemical composition of the plant.

\section{Results}

The results of this study showed that the biomass of Brachiaria ruziziensis increased significantly $(P<0.05)$ with phenological stage. The phenological stage has variably affected the chemical composition of the Brachiaria ruziziensis. The dry matter and fibre content of Brachiaria ruziziensis increased at the phenological stage whilst the concentration of crude protein, digestibility of organic matter and metabolizable energy of Brachiaria ruziziensis decreased significantly $(P<0.05)$. However, the concentration of carbohydrates in the plant increased significantly $(P<0.05)$ with the phenological stage.

\section{Conclusion}

This study shows that harvesting/feeding at the flowering stage may be recommended for this forage crop because it combines both high biomass and forage with good nutritional value.

\footnotetext{
${ }^{\dagger}$ E-mail: ftendonkeng@yahoo.fr
} 